\title{
A Description of Moral Values in JK Rowling's Novel Harry Potter and Prisoner of Azkaban and their Application to Indonesian Morality Education
}

\author{
Ainun Ralia \\ English Education Study Program, Department of Language and Art \\ Universitas Bengkulu \\ ainun25.ralia@gmail.com \\ Kasmaini \\ English Education Study Program, Department of Language and Art \\ Universitas Bengkulu \\ kasmainiunib@gmail.com \\ Indah \\ English Education Study Program, Department of Language and Art \\ Universitas Bengkulu
}

\begin{abstract}
The research aims to find out the moral value in novel and their application to Indonesia morality education. The object of this research is a novel with title Harry Potter and Prisoner of Azkaban by JK Rowling. This research was using qualitative as the methodology and the data was collected by checklist data sheet as an instrument. The checklist consisted of 21 items which represent the moral value base on its types. This research uses Linda theory. The result of data analysis shows that there are 89 items moral value in the novel and all value can be application in Indonesia morality by using 5 value from Character Education in K13. From the results, it is concluded that people in a novel always bring some value which related to education and teacher need to know how to use it.
\end{abstract}

Keywords: Moral Values, Education

\section{Background}

In daily life, a human cannot be separated with moral. Moral has given effect for attitude and characteristic of human life. Development of value cannot be stopped, because the value has born by the society. Morality came from the Latin "moralis " means manner, character, and proper of behavior. According to Oxford dictionary is a principle concerning the 
distinction between right and wrong or good and bad behavior. Moral can be a body of standards or principles which are derived from a code that conducts from a particular philosophy, religion or culture, or it can be derived from a standard that a person believes in universal. Moral has a similar meaning to rule of how individual people should behave.

In literature, a writer puts some values in their product to give effect to the reader. It is usually called moral value or educational value. Moral education has a correlation to the literature such as a novel, short story, poem and so on. This moral is a proper behavior which can be applied to society. Moral education relates to student and young generation. The writer gives the values in their novel in order to describe the value using the character in novel and storyline of the novel. As the result a reader can learn the manner of the character and apply it to their daily life.

Moral can be applied in the education field. Commonly, moral education relates to how to improve student morality. Moral of education is used to give an example of a good attitude towards society. The concept of moral education can be found in literature formation. Many teachers use literature to teach education value such as honesty, brave, kind and friendship. For example, in a novel or short story, an actor has individual character, in this case, the protagonist has good character: nice, humble, forgiveness, and so on, while antagonist has bad character: egoistic, cruel, jealous and so on. From all descriptions, the students could learn that how good behavior can influence the life. The main character can solve all problems which were found to use his/her capability.

In Bengkulu, there are some problems correlated to moral such as Genk Motor and rape. First is Genk or grouping. It means a number of people or organization that has the same interests, aims, or characteristics and are often part of the larger group (oxford advanced learners dictionary). In school students usually make a group for learning all together or 
just only friendship, which is based on their interest. In reality, the student made this group for some reasons, for example, group work for studying, confiding and so on. A student who cannot be a member of a group of some students, it possible that she or he will get bullying by the other students. This condition is not only found in television but also be found in reality. For joining the group of students, are selected by some criteria such as smart for group work for studying, have a motorcycle for group motorbike. Hence, the students need to fulfill the criteria to join the group. From the explanation above, the student asserts themselves to fulfill the criteria meanwhile they parents may get difficulty to follow what their child demand, while student didn't join the group they may be got bullying.

Second delinquency by the young generation, it means that bad or criminal behavior, which is usually done by young people (Oxford advanced learner's dictionary). It happens because at the impact of moral decreased in education. There is some news in television, newspaper, and network about delinquency that had been done by the student. One famous story in Bengkulu is raped by some boys toward girls and the reason is jealous and drunk by tuak. Not only that many robbers were doing by a junior student but also by high school student. The reason is that they need money to buy drugs and smoking. Some harassment are done by boy and old man toward girls because their desire and it makes student quit from their school since they have been pregnant. It is very disappointing. Alternatively, government starts to develop a curriculum to help concerning of characters education the teacher to improve student attitude. The other example is the young generation difficult to control their self toward a new aspect of society.

Many kinds of thing can be studied by the students. One of them is literature. The development of literature gives effect to society and education. The function of media can influence the education field. For instance, The teacher can use a novel as a media to teach about moral value, which can improve the quality of students behavior. This situation 
motivates the effort in changing of school learning to solve the problem of students who felt bored and uninterested. Thus, the teacher need to find a way to solve this problem and use the novel to make a learning activity more interesting and interactive.

The researcher chooses HarryPotter because of the author. JK Rowling is a single parent who lived in poverty, but from her life, the researcher learns not to give up to your condition. Still, learn and study although you are not in school anymore. The very inspiration of JK Rowling is her lived, she divided her money from harry potter profit's to people. She never gives up from poverty and always remembers hod hard life around poverty. Many aspects can be learned from her.

Prisoner of Azkaban will be analyzed by the researcher. This novel focuses on friendship and forgiveness. We can see this in the storyline of the novel. In pages 18-19 in end of the paragraph, Ron obviously realized that he'd gotten Harry into trouble because he hadn't called again. Ron is a character which is one of Harry Potter's best friends. This is an evidence of Harry Potters friendship. From all, the story student can learn some values to improve their character.

Not only friendship but believes, forgiveness and solving problem, how the main character solves his problem. Then, it show How the main character learns to control his emotion toward Sirius Black whom people think is the killer of Harry Potter parents. But actually it was not Sirius Black, but the other friend who become a traitor and make Sirius Black become a scapegoat. It has shown how Harry solves these problems and the readers can also learn from its. Many problems before the climax of this novel will show to the reader of how good the friendship of the three main characters Hermione, Ron, and Harry. 
There are some similar research had conducted an analysis of moral values for example taken from Edensor Novel by Andrea by Dani Atik Susanti. Moral values that found in the research as never give up, nationalism, empathy to each other, the strength of heart, optimism and thinking positively, believe in God, there is no reason to stop learning to struggle for life. In presenting the moral values, the author uses explicit meaning, implicit meaning, and imagination. Second is Education Value in "Finding Nemo" Movie by Yuni Mitayani. The result of this study is there are some education values in the "Finding Nemo" movie like love and affection, respectful, loyal and trustworthy, bravery, selfreliability, kind and friendly, sensitive and not selfish, honesty, leadership, and sacrifice. The different with the researcher is English novel with the different culture from Indonesia and not really describing how this can be useful for education.

From all of the explanations above, the researcher wants to find out what are in the from Harry Potter novel and how the value can be applied to education. The novel is Harry Potter and Prisoner of Azkaban by JK Rowling, the reason for choosing is because of the storyline and background of the writer.

\section{METHOD}

This research was a descriptive qualitative research. Qualitative research is a research design part of the qualitative method that allows the researcher to describe a phenomenon by presenting the facts in rich detail without attempting to interpret them. The form of report is in statistical form. In this case the researcher used checklist forms to divide the value.

The object of the research was the script of Harry Potter Prisoner of Azkaban Novel. The researcher was reading and learning all sentences from the novel text. After that, the researcher was extracting the moral values which implied in the novel by relating to the theory 
of moral values. The last step was concluding the data analysis in order to answer the statement of the problem. 


\section{RESULT AND DISCUSSION}

\subsection{Result}

In this section, the researcher presents the result of the research that has been conducted. The result is divided into two they are the moral value found and their application to Indonesia morality education.

In "Harry Potter and Prisoner of Azkaban" the researcher got the value, which has found based on the intrinsic elements and storyline. They were; honestly, bravery, confidence, loyalty, trustworthy, altruism, kindness, sensitiveness, and friendship.

The second is the application of moral values to Indonesia morality education. The researcher categorized those into some values which related to Morality education. In education character, there are five kinds of morals, Religius, Integritas, Mandiri, Gotong Royong and Nasionalis. From that value, there are some similarities with moral values in novel Harry Potter and Prisoner of Azkaban and in curriculum.

The value Religius value have some kind of values such as: faith, tolerance and trustworthy. In Harry Potter novel there are two moral value related to Religius value, those are trusworthy and sensitive. Sensitive relates to tolerance which deals to be sensitive in society problem. It will develop a tolerance between other. Religion teaches people about honestly and make an individual became a trustworthy person.

The Nasionalis value relates to loyalty value. It is a way of developing feeling of love and care to the problem in their country. In Harry Potter novel, there is a honest value, which 
relates to Integritas value from Education character. It uses to explain the quality of individual behavior. In this case, the value student learns about politeness. They use sensitive value for help them for applying politeness and also they can be altruism in society, so it can establish the society. Indepedent or Mandiri value is related to bravery value and confidence value from the novel. If an individual become independent, he needs to be confidence about his thought and action, not only that he or she needs brave to take all of action in their life. The last value in education character is Gotong Royong, from this value teacher can make a relation to some moral values such as kindness, friendship and altruism. From three moral values, student able to understand what are they need to practice in Gotong Royong value.

\section{Suggestions}

In relation to the conclusions, suggestions are given as the following:

For the educator, the researchers hope this researcher's can use as a media to teaching-learning, especially in reading the subject. The teachers can use the novel as a media or material to improve the student's vocabulary. The novel can give students more example of a role model. On the other hand, the researcher also hopes that the educator, can use as a source of knowledge, we know reading is the most source of knowledge. Novel innovations can increase the desire to read. It will be able to give some educational value and shaping their characters in teaching and learning process to make the students accidentally get knowledge about the educational values.

For the students, reading the novels has many benefits. Not only fun but a novel can give them many messages. They can get inspirations, education, religious, shaping their characters and get the motivation to achieve their dreams. 


\section{REFERENCES}

Arsyad,Azhar.(2011).Media Pembelajaran.Jakarta: Rajagrafindo Persada.

Barcalow, Emmett. (1994).Moral Philosophy: Theory and Issues. California: Wadsworth Publishing Company.

Echols, John M. And Hassan Shadily,(2015).Kamus Inggris Indonesia. PT Gramedia Pustaka: Jakarta

Fitrianiy, Rafy, dkk.(no tahun). An Analysis Of Moral Values In Novel "Oliver Twist” By Charles Dicken. Unpublished Thesis.University of Pasir Pengairan

Hornby, A.S. 1989., Oxford Learner's Dictionary of Current English.

New York:Oxford University Press

Hunt, Elgin F. and Colander, David C. 1984. Social Science an Introduction to the Study of Science. Macmillan Publishing Company: New York

Hurlock, Elizabeth B. 1985. Child Development. McGraw-Hill Book Company: New York.

Fitriani, R,. Rafi A,. \& Pipit R. 2017. Analysis of Moral Values in Novel Oliver Twist By Charles Dickens. 2015. Unpublished Thesis.University of Pasir Pengaraian

Juwita, Panisia.(2018).An Analysis of Childhood Good Values in C.S.Lewis's Novel The Voyage of the Dawn Treader. UNIB

Kemendibud (PPT).(2013). Konsep dan implementasi kurikulum 2013. Jakarta.

Revisi Kurikulum 2013.(2015) Jakarta : Kemendikbud

Little, Graham. 1970. Approach To Literature An Introduction To Critical

Study Of Content And Method In Writing. Australia: Science

Mitayani, Yunita.(2010).Educational Values In The "Finding Nemo" Movie. Unpublished Thesis. STAIN Salatiga

Moleong,LexyJ.(2009). Metode Penelitian Kualitatif. Bandung: Remaja Rosda Karya.

Mulat, Sri.(2010).An Analysis of Moral Values in the Novel Bumi Cinta (Habiburrahman ElShirazy), Unpublished Thesis,STAIN Salatiga.

Mulgan, John, and Davin, D. M. (1950).An Introduction to English Literature.London: Oxford University Press.

Oxford. 2015. Oxford Advanced Learner's Dictionary. New York : Oxford University Press

Sigelman, Carol. K and Shaffer, R. David. 1995. Life-Span Human Development. Books/Cole Publishing Company: California.

Stewig, John Warren. 1980. Children and Literature. USA: Houghton Mifflin Company

Surjowati,Ribut.(tanpa Tahun). EDWARD MORGAN FORSTER AND HIS ASPECTS OF

THE NOVEL .Universitas Wijaya Kusuma :Surabaya

Susanti, Dani Atik.(2012). An Analysis Of Moral Values Taken From Endensor

Novel By Andre Hinata".Unpublished Thesis. STAIN Salatiga

Suryaningrum, Dyah,dkk.(no year).The Analysis Of Moral Values In The Novel Sense And Sensibility. Unpublished Thesis. Tanjung Putra University

Syam, Noor. M. Drs, DKK. 1988. Pengantar Dasar-Dasar Kependidikan. Usaha Nasional: Surabaya.

Wibowo, Agus. (2012). PendidikanKarakter "Strategi Membangun Karakter

Bangsa Berperadaban".Jogjakarta: Pustaka Pelajar.

Wikipedia.co.id 